\title{
ANALISIS PENGARUH KONSUMSI BUAH BIT TERHADAP PENINGKATAN KADAR HEMOGLOBIN PADA IBU HAMIL TRIMESTER III
}

\author{
Liananiar $^{1)}$, Fatma Sylvana Dewi Harahap ${ }^{2)}$, Elvi Era Liesmayani ${ }^{3)}$ \\ ${ }^{1}$ Mahasiswi, S2 Pasca Sarjana Institut Kesehatan Helvetia \\ ${ }^{2,3}$ Dosen, S2 Pasca Sarjana Institut Kesehatan Helvetia \\ Email : liananiar02@gmail.com
}

Diterima: Juli 2019, Diterbitkan: Juni 2020

\begin{abstract}
ABSTRAK
Buah bit mampu merangsang, membangun, membersihkan, dan memperkuat sistem peredaran darah dan sel darah merah sehingga dapat membawa zat tubuh dan dapat mencegah kurangnya sel darah merah dalam tubuh. Hemoglobin merupakan bagian dari darah yang mengandung protein kaya zat besi. Kehamilan trimester III yaitu periode 3 bulan terakhir kehamilan yang dimulai pada minggu ke28 sampai minggu ke-40. Hasil survei yang dilakukan terhadap 50 orang ibu hamil didapatkan hasil yang memeriksa hemoglobin yaitu 30 dari 50 ibu hamil didapatkan hasil $\mathrm{Hb} \geq 11 \mathrm{gr} / \mathrm{dL}$. Tujuan penelitian ini yaitu untuk menganalisis pengaruh faktor yang mempengaruhi kadar $\mathrm{Hb}$ ibu hamil trimester III di UPTD Puskesmas Jeumpa Kabupaten Bireuen Tahun 2019. Desain yang digunakan ialah Pretest-Posttest Control Group Desaign. Populasi dalam penelitian ini adalah 50 orang ibu hamil trimester III dengan jumpah sampel 24 orang, yaitu 12 responden untuk kelompok eksperimen dan 12 responden untuk kelompok kontrol. Berdasarkan analisis uji $t$-test berpasangan pada kelompok eksperimen menunjukkan bahwa nilai $p$ value adalah 0,002 hal ini berarti $\mathrm{p}<0,05$, maka terdapat perbedaan kadar hemoglobin yang signifikan antara kadar hemoglobin pre-test dan kadar hemoglobin post-test dengan mengkonsumsi buah bit. Bagi petugas kesehatan agar memberikan informasi kadar hemoglobin sebelum dan setelah pemberian buah bit pada ibu hamil agar dapat dijadikan dasar pengambilan keputusan dalam usaha meningkatkan kadar $\mathrm{Hb}$ dan mencegah kejadian anemia, referensi untuk membuat suatu produk ekstrak buah bit.
\end{abstract}

Kata Kunci : Buah Bit, Hemoglobin, Anemia, Ibu Hamil Trimester III

\section{ABSTRACT}

Beetroot is able to stimulate, build, cleanse, and be able to strengthen the circulatory system and red blood cells so that it can carry body substances and can prevent the lack of red blood cells in the body. Hemoglobin is part of the blood that contains iron-rich protein. The third trimester of pregnancy is the last 3 months period of pregnancy which starts on the 28th week until the 40th week. The results of a survey conducted on 50 pregnant women obtained results that examined hemoglobin, 30 of 50 pregnant women obtained $\mathrm{Hb}$ results of $\geq 11 \mathrm{gr} / d L$. The purpose of this study was to analyze the effect of factors affecting $\mathrm{Hb}$ levels in third trimester pregnant women in the UPTD of Jeumpa District Health Center Bireuen District in 2019. The design used in this was the Pretest-Posttest Desaign Control Group approach. The population in this study were 50 third trimester pregnant women with a sample of 24 people, 12 respondents for the experimental group and 12 respondents for the control group. Based on the analysis of paired t-test test in the experimental group showed that the value of $p$ value is 0.002, this means $p<0.05$, then there is a significant difference in hemoglobin levels between the hemoglobin level pre-test and hemoglobin level post-test by consuming beetroot. For health workers to provide information on hemoglobin levels before and after giving beetroot to pregnant women so that it can be used as a basis for decision making in an effort to increase Hb levels and prevent the occurrence of anemia, a reference to making a product of beetroot extracts.

Keywords: Beetroot, Hemoglobin, Anemia, Trimester III Pregnant Women. 


\section{PENDAHULUAN}

Hemoglobin merupakan senyawa pembawa oksigen pada sel darah merah. Hemoglobin di dalam darah membawa oksigen dari paru-paru ke seluruh jaringan tubuh dan membawa kembali karbondioksida dari seluruh selke paru-paru untuk dikeluarkan dari tubuh. Kadar hemoglobin merupakan indikator biokimia untuk mengetahui status gizi ibu hamil.

Meningkatnya plasma sebanyak tiga kali pada jumlah sel darah merah akan menyebabkan penurunan perbandingan HemoglobinHematokrit sehingga akan meningkatkan risiko anemia fisiologis pada saat hamil. Kadar $\mathrm{Hb}$ ibu hamil harus selalu berada pada kondisi normal yaitu $11 \mathrm{gr} / \mathrm{dl}$. Jika kadar $\mathrm{Hb}$ ibu hamil berada dibawah normal maka dapat dikatakan ibu hamil tersebut mengalami anemia (Proverawati \& Siti, 2010)

Menurut WHO (2015), klasifikasi anemia berdasarkan derajat keparahan adalah ringan $(10,0-10,9 \mathrm{gr} / \mathrm{dl})$, sedang $(7,0-9,9 \mathrm{gr} / \mathrm{dl})$, dan berat $(<7,0 \mathrm{gr} / \mathrm{dl})$.

Anemia tidak dapat disepelekan bila terjadi saat hamil terutama pada saat kehamilan trimester III dapat menimbulkan risiko seperti keguguran, kelahiran prematur, pendarahan pasca melahirkan, hingga bayi lahir dengan cacat bawaan. Mengingat dampaknya yang dapat membahayakan ibu hamil dan janin, maka ibu hamil sebaiknya mewaspadai setiap gejala anemia yang muncul (Sudasiah, 2016)

Buah bit mengandung vitamin dan mineral yang memiliki banyak sekali manfaat. Bit mampu merangsang membangun, membersihkan dan memperkuat sistem peredaran darah dan sel darah merah sehingga darah dapat membawa zat tubuh dan dapat mencegah kurangnya sel darah merah dalam tubuh. Di Eropa Timur umbi bit ini sudah cukup dikenal dan digunakan untuk pengobatan penyakit leukemia (WHO, 2015).

Menurut laporan World Health Organization (WHO) tahun 2010 Angka
Kematian Ibu (AKI) di dunia yaitu 289.000 jiwa. Beberapa Negara memiliki AKI cukup tinggi seperti Afrika Sub-Saharan 179.000 jiwa, Asia Selatan 69.000 jiwa,dan Asia Tenggara 16.000 jiwa. Angka kematian ibu di negara-negara Asia Tenggara yaitu Indonesia 190per 100.000 kelahiran hidup, Vietnam 49 per 100.000 kelahiran hidup, Thailand 26 per 100.000 kelahiran hidup, Brunei 27 per 100.000 kelahiran hidup, dan Malaysia 29 per 100.000 kelahiran hidup.

Di Indonesia umumnya kadar hemoglobin $(\mathrm{Hb})$ yang kurang disebabkan oleh kekurangan zat besi. Kekurangan zat besi dapat menimbulkan gangguan atau hambatan pada pertumbuhan janin baik sel tubuh maupun sel otak. Kadar $\mathrm{Hb}$ yang tidak normal dapat mengakibatkan kematian janin dalam kandungan, abortus, cacat bawaan, Berat Badan Lahir Rendah (BBLR), kadar $\mathrm{Hb}$ tidak normal pada bayi yang dilahirkan, hal ini menyebabkan morbiditas dan mortalitas ibu dan kematian perinatal secara bermakna lebih tinggi (WHO, 2015)

Berdasarkan Profil Kesehatan Aceh tahun 2016, Angka Kematian Ibu di tujuh tahun terakhir juga berfluktuasi. Dari data yang bersumber pada dinas kesehatan kabupaten/kota, diketahui jumlah kematian ibu di Aceh yang dilaporkan adalah 169 kasus dan lahir hidup 101.249 jiwa, maka rasio angka kematian ibu di Aceh tahun 2016 sebesar 167 per 100.000 kelahiran hidup, meningkat dari tahun sebelumnya yaitu 134 per 100.000 kelahiran hidup. Hal ini menunjukkan semakin baiknya pelayanan kesehatan di fasilitas kesehatan.

Hasil survei awal yang dilakukan oleh peneliti terhadap 50 orang ibu hamil trimester III pada bulan Juni s/d Agustus 2018 didapatkan bahwa ibu hamil trimester III yang berkunjung ke laboratorium UPTD Puskesmas Jeumpa yang memeriksa hemoglobin yaitu 30 dari 50 ibu hamil didapatkan hasil $\mathrm{Hb} \geq 11 \mathrm{gr} / \mathrm{dL}$. Hal ini menunjukkan bahwa ditemukan perbedaan dengan data Dinas Kesehatan Provinsi Aceh yaitu ibu hamil dengan kasus anemia. 
Sehingga sangat penting bagi seorang ibu untuk melakukan pemeriksaan $\mathrm{Hb}$ di karenakan banyak masalah ataupun penyulit yang akan terjadi baik saat kehamilan, persalianan, dan nifas.

Tujuan penelitian ini yaitu untuk "Menganalisis Pengaruh Faktor Yang Mempengaruhi Kadar $\mathrm{Hb}$ Ibu Hamil Trimester III Di Wilayah Kerja UPTD Puskesmas Jeumpa Kabupaten Bireuen Tahun 2018".

\section{METODE PENELITIAN}

Desain yang digunakan dalam penelitian ini adalah True Experimental Design (eksperimen yang betul-betul), karena dalam penelitian ini peneliti dapat mengontrol semua variabel luar yang mempengaruhi jalannya eksperimen. Pengelompokan anggota sampel yang digunakan untuk kelompok eksperimen dan kelompok kontrol dipilih secara random dari populasi tertentu. Penelitian ini menggunakan pendekatan Pretest-Posttest Control Group Desaign. Dalam hal ini dilihat perbedaan pencapaian antara kelompok eksperimen dengan pencapaian kelompok kontrol (Sugiyono, 2017)

Penelitian ini dilakukan di UPTD Puskesmas Jeumpa Kabupaten Bireuen Provinsi Aceh adalah lokasi yang sangat sesuai untuk dilakukan penelitian, dikarenakan dari hasil survei awal peneliti mendapatkan kasus ibu hamil trimester III sebanyak 30 orang dengan hasil wawancara ibu mengkonsumsi buah bit dan didapatkan hasil pemeriksaan laboratorium rata-rata $\mathrm{Hb}$ 11-16 gr//dL.

Populasi adalah wilayah generalisasi yang terdiri atas obyek/subyek yang mempunyai kualitas. dan karakteristik tertentu yang ditetapkan oleh peneliti untuk dipelajari dan kemudian ditarik kesimpulannya. Populasi dalam penelitian ini yaitu seluruh ibu hamil trimester III yang berkunjung ke UPTD Puskesmas Jeumpa sebanyak 50 orang selama bulan Februari sampai dengan bulan Maret 2019. Sampel adalah bagian dari jumlah dan karakteristik yang dimiliki oleh populasi tersebut. Apabila ukuran populasi sebanyak kurang lebih dari 100, maka pengambilan sampel sekurang-kurangnya $50 \%$ dari populasi. Apabila ukuran populasi sama dengan atau lebih dari 1000 ukuran sampel diharapkan sekurang-kurangnya $15 \%$ dari ukuran populasi. Teknik pengambilan sampel pada penelitian ini adalah Probability Sampling dengan cara simple random sampling selama 5 minggu dimulai pada tanggal 05 Februari s/d 12 Maret 2019 pada ibu hamil trimester III yang berkunjung sebanyak 24 orang dan akan dibagi menjadi 2 kelompok yaitu 12 orang yang diberi perlakuan dan 12 orang yang tidak diberi perlakuan (Iman, 2016)

Data primer dalam penelitian ini adalah data yang diperoleh melalui wawancara langsung kepada responden dengan berpedoman pada kuesioner penelitian. Data sekunder dalam penelitian ini adalah data yang di dapatkan dari Kabupaten, BKKBN, data dari UPTD Puskesmas Jeumpa. Data tertier dalam penelitian ini adalah studi kepustakaan seperti jurnal yang di publikasikan data dari WHO dan SDKI.

Metode pengumpulan data dilakukan dengan mewawancarai secara mendalam kepada informan yang mewakili. Alat ukur dan instrument penelitian yang dapat diterima sesuai standar adalah menggunakan $\mathrm{Hb}$ Sahli.mendalam kepada informan yang mewakili. Alat ukur dan instrument penelitian yang dapat diterima sesuai standar adalah menggunakan $\mathrm{Hb}$ Sahli.

\section{HASIL}

Berdasarkan tabel distribusi responden menurut pemberian buah bit tersebut, diketahui bahwa kadar $\mathrm{Hb}$ dari sebelum pemberian buah bit dan saat pemberian buah bit semakin bertambah.

Responden dalam penelitian ini adalah ibu hamil trimester III yang berkunjung ke UPTD Puskesmas Jeumpa Kabupaten Bireuen yang di periksa hemoglobinnya sebelum dan sesudah diberi buah bit. Lebih jelasnya distribusi responden pemberian buah bit dalam 
penelitian ini dapat dilihat pada tabel dibawah ini.

Tabel 1. Distribusi Responden Menurut Kelompok Pemberian Buah Bit

\begin{tabular}{ccccccc}
\hline No & $\begin{array}{c}\text { Pre- } \\
\text { Test }\end{array}$ & M1 & M2 & M3 & M4 & M5 \\
\hline 1 & 9.1 & 9.3 & 9.4 & 9.7 & 9.9 & 10 \\
2 & 12.8 & 12.8 & 13 & 13.2 & 13.4 & 13.5 \\
3 & 10.8 & 10.8 & 10.8 & 10.9 & 11 & 11 \\
4 & 9.3 & 9.3 & 9.5 & 9.8 & 9.9 & 10 \\
5 & 11.3 & 11.4 & 11.6 & 11.7 & 11.9 & 12 \\
6 & 10.7 & 10.7 & 10.8 & 10.8 & 10.9 & 11 \\
7 & 12 & 12.1 & 12.1 & 12.5 & 12.8 & 13 \\
8 & 10 & 10.1 & 10.3 & 10.5 & 10.8 & 11 \\
9 & 10.5 & 10.5 & 10.7 & 10.8 & 11 & 11 \\
10 & 12.5 & 12.5 & 122.6 & 12.6 & 12.8 & 13 \\
11 & 10.2 & 10.2 & 10.4 & 10.6 & 10.8 & 11 \\
12 & 13 & 13.1 & 13.3 & 13.5 & 13.8 & 13.9 \\
\hline Sumber: Hasil Penelitian & 2019 & &
\end{tabular}

Sumber: Hasil Penelitian 2019

\section{Grafik 1. Peningkatan kadar $\mathrm{Hb}$ Kelompok Eksperimen}

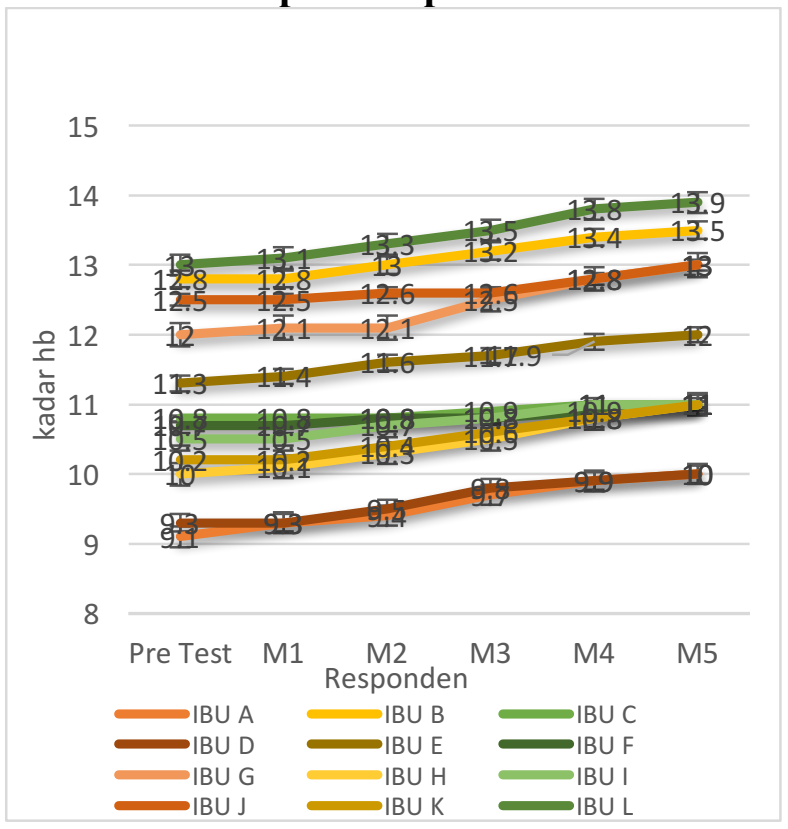

Berdasarkan grafik 1, hasil peningkatan kadar $\mathrm{Hb}$ kelompok Eksperimen maka dapat disimpulkan bahwa terjadi peningkatan kadar hemoglobin secara bertahap pada ibu hamil trimester III. Angka kenaikan kadar $\mathrm{Hb}$ yang tertinggi pada kelompok eksperimen adalah Pre-Test 13,0 mg/dL - $\mathrm{M}_{\mathrm{I}} 13,1$ $\mathrm{mg} / \mathrm{dL}-\mathrm{M}_{\text {II }} 13,3 \mathrm{mg} / \mathrm{dL}-\mathrm{M}_{\text {III }} 13,5 \mathrm{mg} / \mathrm{dL}$ - $\mathrm{M}_{\mathrm{IV}} 13,8 \mathrm{mg} / \mathrm{dL}-\mathrm{M}_{\mathrm{V}} 13,9 \mathrm{mg} / \mathrm{dL}$. Sedangkan angka kadar $\mathrm{Hb}$ yang terendah adalah Pre-Test 9,1 mg/dL - $\mathrm{M}_{\mathrm{I}}$ 9,3 mg/dL - $\mathrm{M}_{\text {II }}$ 9,4 mg/dL - $\mathrm{M}_{\text {III }}$ 9,7 mg/dL - $\mathrm{M}_{\text {IV }}$ 9,9 $\mathrm{mg} / \mathrm{dL}-\mathrm{M}_{\mathrm{V}} 10,0 \mathrm{mg} / \mathrm{dL}$.

\begin{tabular}{|c|c|c|c|c|c|c|}
\hline No & $\begin{array}{l}\text { Pre- } \\
\text { Test }\end{array}$ & M1 & M2 & M3 & M4 & M5 \\
\hline 1 & 8.1 & 8.1 & 8.5 & 8.3 & 8.4 & 9 \\
\hline 2 & 10.5 & 10.5 & 10.4 & 10.5 & 10.2 & 10.0 \\
\hline 3 & 10.0 & 10.1 & 10.0 & 9.8 & 10.1 & 10.0 \\
\hline 4 & 12.1 & 12.1 & 12.0 & 12.1 & 11.9 & 12.0 \\
\hline 5 & 9.1 & 9.1 & 9.5 & 9.7 & 9.7 & 10.0 \\
\hline 6 & 12.4 & 12 & 12.3 & 12.8 & 12.5 & 13.0 \\
\hline 7 & 10.1 & 10.1 & 10 & 10.2 & 10 & 10.0 \\
\hline 8 & 11.1 & 11.1 & 11.0 & 10.8 & 11.0 & 11.0 \\
\hline 9 & 8.9 & 8.9 & 9.0 & 9.2 & 9.1 & 9.0 \\
\hline 10 & 11.0 & 11.0 & 10.8 & 10.9 & 11 & 11.0 \\
\hline 11 & 9.5 & 9.5 & 9.6 & 9.5 & 9.9 & 10.0 \\
\hline 12 & 11.5 & 11.4 & 11.1 & 11.5 & 11.7 & 11.9 \\
\hline
\end{tabular}

Sumber: Hasil Penelitian 2019

\section{Grafik 2. Peningkatan kadar $\mathrm{Hb}$ Kelompok Kontrol}

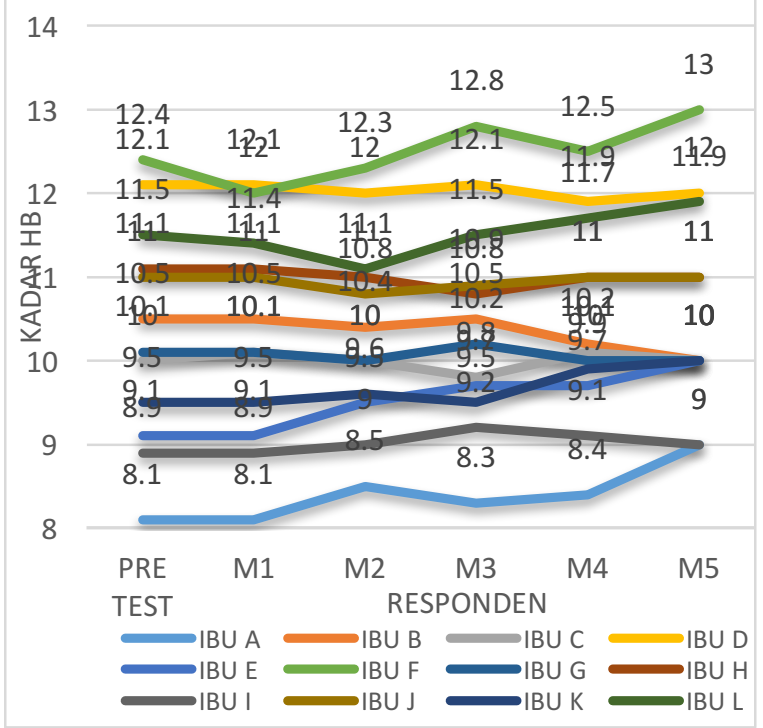

Sumber: Hasil Penelitian 2019

Berdasarkan grafik 2, hasil peningkatan kadar $\mathrm{Hb}$ kelompok kontrol 
maka dapat disimpulkan hasil bahwa terjadi perubahan kadar hemoglobin naik turun pada ibu hamil trimester III. Angka kenaikan kadar $\mathrm{Hb}$ yang tertinggi pada kelompok kontrol adalah, Pre-Test 12,4 $\mathrm{mg} / \mathrm{dL}-$ MI $12,0 \mathrm{mg} / \mathrm{dL}-$ MII $12,3 \mathrm{mg} / \mathrm{dL}$ - MIII 12,8 mg/dL - MIV 12,5 mg/dL MV 13,0 mg/dL. Sedangkan angka kadar $\mathrm{Hb}$ yang terendah adalah, Pre-Test 8,1 $\mathrm{mg} / \mathrm{dL}-\mathrm{M}_{\mathrm{I}} 8,1 \mathrm{mg} / \mathrm{dL}-\mathrm{M}_{\mathrm{II}} 8,5 \mathrm{mg} / \mathrm{dL}-$ $\mathrm{M}_{\text {III }} 8,3 \mathrm{mg} / \mathrm{dL}-\mathrm{M}_{\mathrm{IV}} 8,4 \mathrm{mg} / \mathrm{dL}-\mathrm{M}_{\mathrm{V}} 9,0$ $\mathrm{mg} / \mathrm{dL}$.

Distribusi kadar hemoglobin awal (Pre-test) pada ibu hamil trimester III kelompok eksperimen dan kontrol dapat dilihat pada tabel 3 .

\begin{tabular}{ccccc} 
Tabel 3. Kadar Hb Awal (Pre-Test) Ibu \\
Hamil Trimester III Kelompok \\
Eksperimen dan Kelompok \\
Kontrol \\
\hline \multirow{5}{*}{ Kelompok } \\
Kada Hb & Eksperimen & \multicolumn{3}{c}{ Kelompok Kontrol } \\
\cline { 2 - 5 } & $\mathbf{F}$ & $\mathbf{\%}$ & $\mathbf{F}$ & $\mathbf{\%}$ \\
\hline $8,1-9,0$ & 0 & 0 & 2 & 16,7 \\
$9,1-10,0$ & 3 & 25 & 3 & 25 \\
$10,1-11,0$ & 4 & 33,3 & 3 & 25 \\
$11,1-12,0$ & 2 & 16,7 & 2 & 16,7 \\
$12,1-13,0$ & 2 & 16,7 & 2 & 16,7 \\
$13,1-14,0$ & 1 & 8,3 & 0 & 0 \\
\hline Jumlah & $\mathbf{1 2}$ & $\mathbf{1 0 0}$ & $\mathbf{1 2}$ & $\mathbf{1 0 0}$ \\
\hline Sumber & &
\end{tabular}

Sumber: Hasil Penelitian 2019

Berdasarkan tabel 3 dapat diketahui bahwa distribusi kadar hemoglobin awal (Pre-test) pada ibu hamil trimester III kelompok eksperimen kadar hemoglobin sebagian besar terletak pada nilai 10,1-11,0 sedangkan pada kelompok kontrol kadar hemoglobin sebagian besar terletak pada nilai 9,1-11,0.

Tabel 4. Ukuran Pemusatan dan Ukuran Penyebaran Kadar Hemoglobin Awal (Pre-test) Ibu Hamil Trimester III Kelompok Eksperimen dan Kontrol

\begin{tabular}{ccc}
\hline & $\begin{array}{c}\text { Kelompok } \\
\text { Eksperimen }\end{array}$ & $\begin{array}{c}\text { Kelompok } \\
\text { Kontrol }\end{array}$ \\
\hline Mean & 11,142 & 10,717 \\
Median & 11,000 & 10,700 \\
Modus & 11,0 & 8,9 \\
\hline
\end{tabular}

\begin{tabular}{ccc}
\hline $\begin{array}{l}\text { Standar } \\
\text { Deviasi }\end{array}$ & 1,2362 & 1,4031 \\
\hline Sumber Hasil Penelitian 2019 &
\end{tabular}

Sumber: Hasil Penelitian 2019

Data kadar hemoglobin awal (Pretest) pada kelompok eksperimen dan kontrol diketahui normal. Maka mean kadar hemoglobin awal (Pre-test) pada kelompok eksperimen adalah 11,142 (SD 1,2362) sedangkan mean kadar hemoglobin awal (Pre-test) pada kelompok kontrol adalah 10,717 (SD 1,4031). Rata -rata kadar hemoglobin awal (pre-test) pada kelompok eksperimen lebih tinggi dari pada kelompok kontrol.

\section{Kadar Hemoglobin Akhir (Post-Test) Pada Ibu Hamil Trimester III Kelompok Eksperimen dan kontrol}

Berdasarkan uji normalitas data menggunakan One-Sample Shapiro-Wilk Test yang dilakukan terhadap kadar hemoglobin akhir (Post-test) pada kelompok eksperimen diketahui bahwa nilai $\mathrm{p}$ value yaitu 0,199 dan kadar hemoglobin akhir (Post-test) pada kelompok kontrol diketahui bahwa nilai $\mathrm{p}$ value pada yaitu 0,237 .

Berdasarkan tabel 4.5 terlihat bahwa nilai probabilitas ( $\mathrm{p}$ value) pada kelompok eksperimen dan kontrol lebih besar dari 0,05. Berdasarkan hasil uji normalitas yang dilakukan, dapat disimpulkan bahwa semua data terdistribusi normal dan bisa diuji parametrik.

Distribusi kadar hemoglobin akhir (Post-test) pada santri putri kelompok eksperimen dan kontrol dapat dilihat pada tabel di bawah ini:

Tabel 5. Kadar Hb Akhir (Post-Test)

Ibu Hamil Trimester III Kelompok Eksperimen dan Kelompok

Kontrol

\begin{tabular}{ccccc}
\hline \multirow{2}{*}{ Kadar Hb } & \multicolumn{2}{c}{$\begin{array}{c}\text { Kelompok } \\
\text { Eksperimen }\end{array}$} & \multicolumn{2}{c}{$\begin{array}{c}\text { Kelompok } \\
\text { Kontrol }\end{array}$} \\
\cline { 2 - 5 } & F & $\%$ & F & $\%$ \\
\hline $8,1-9,0$ & 0 & 0 & 2 & 16,7 \\
$9,1-10,0$ & 2 & 16,7 & 5 & 41,7 \\
$10,1-11,0$ & 5 & 41,7 & 2 & 16,7 \\
\hline
\end{tabular}




\begin{tabular}{ccccc}
\hline $11,1-12,0$ & 2 & 16,7 & 2 & 16,7 \\
$12,1-13,0$ & 2 & 16,7 & 1 & 8,3 \\
$13,1-14,0$ & 1 & 8,3 & 0 & 0 \\
\hline Jumlah & $\mathbf{1 2}$ & $\mathbf{1 0 0}$ & $\mathbf{1 2}$ & $\mathbf{1 0 0}$
\end{tabular}

Sumber: Hasil Penelitian 2019

\begin{tabular}{|c|c|c|}
\hline \multicolumn{3}{|c|}{$\begin{array}{l}\text { Berdasarkan tabel 5, dapat } \\
\text { diketahui bahwa distribusi kadar } \\
\text { hemoglobin akhir (Post-test) pada ibu } \\
\text { hamil trimester III kelompok eksperimen } \\
\text { kadar hemoglobin sebagian besar terletak } \\
\text { pada nilai 10,1-11,0 sedangkan pada } \\
\text { kelompok kontrol kadar hemoglobin } \\
\text { sebagian besar terletak pada nilai 9,1-10,0. }\end{array}$} \\
\hline \multicolumn{3}{|c|}{$\begin{array}{c}\text { Tabel 6. Ukuran Pemusatan dan } \\
\text { Ukuran Penyebaran Kadar Hemoglobin } \\
\text { Akhir (Post-test) Kelompok Eksperimen } \\
\text { dan Kontrol }\end{array}$} \\
\hline & $\begin{array}{c}\text { Kelompok } \\
\text { Eksperimen }\end{array}$ & $\begin{array}{c}\text { Kelompok } \\
\text { Kontrol }\end{array}$ \\
\hline Mean & 11,517 & \\
\hline Median & 11,000 & 10,000 \\
\hline Modus & 11,0 & 10 \\
\hline $\begin{array}{l}\text { Standar } \\
\text { Deviasi }\end{array}$ & 1,1472 & 1,1089 \\
\hline
\end{tabular}

Sumber: Hasil Penelitian 2019

Berdasarkan tabel 6, data kadar hemoglobin akhir (Post-test) pada kelompok eksperimen dan kontrol diketahui normal. Maka mean kadar hemoglobin akhir (Post-test) pada kelompok eksperimen adalah 11,517 (SD 1,1472) sedangkan mean kadar hemoglobin akhir (Post-test) pada kelompok kontrol adalah 10,467 (SD 1,1089). Rata -rata kadar hemoglobin akhir (Post-test) pada kelompok eksperimen lebih tinggi dari pada kelompok kontrol.

Berikut ini adalah bentuk penyajian dan interpretasi dari uji statistik Mann Whitney antara selisih Pre-test dan PostTest kadar hemoglobin kelompok eksperimen dan kontrol.

$\begin{gathered}\text { Tabel 7. Selisih Hb Post Test Antara } \\
\text { Kelompok Eksperimen dan } \\
\text { Kelompok Kontrol }\end{gathered}$
\begin{tabular}{llcc}
\multicolumn{4}{c}{} \\
\hline Variabel \\
\hline Rata-Rata & Mean & $\begin{array}{c}\text { P- } \\
\text { value }\end{array}$ & N \\
Selisih Hb & 12,0 & 0,001 & 12 \\
Eksperimen & 9,5 & & 12 \\
Kontrol & 9
\end{tabular}

Sumber: Hasil Penelitian 2019

Berdasarkan hasil tabel 7, rata-rata selisih kadar hemoglobin pada pengukuran kelompok eksperimen adalah 12,0 gr/dl. Pada pengukuran kelompok kontrol didapat rata-rata selisih kadar Hemoglobin adalah 9,5 gr/dl. Hasil uji statistik didapatkan nilai $p=0,0001$, berarti pada alpha $5 \%$ terlihat ada perbedaan yang signifikan antara kelompok eksperimen dan kontrol. Artinya bahwa Terdapat Perbedaan Selisih Kadar Hemoglobin antara Kelompok yang diberi buah bit dengan yang tidak diberi buah bit pada ibu hamil trimester III di UPTD Puskesmas Jeumpa Kabupaten Bireuen tahun 2019.

\section{PEMBAHASAN}

Berdasarkan analisis uji t-test berpasangan pada kelompok eksperimen menunjukkan bahwa nilai $\mathrm{p}$ value adalah 0,002 hal ini berarti $\mathrm{p}<0,05$, maka terdapat perbedaan kadar hemoglobin yang signifikan antara kadar hemoglobin pre-test dan kadar hemoglobin post-test dengan mengkonsumsi buah bit. Berdasarkan hasil tersebut dapat disimpulkan bahwa terjadi peningkatan rata-rata kadar hemoglobin ibu hamil trimester III yang diberikan buah bit pada kelompok eksperimen adalah 11,5 $\mathrm{mg} / \mathrm{dL}$. Angka kenaikan kadar Hb yang tertinggi pada kelompok eksperimen ibu dengan nomor sampel 12 adalah hasil PreTest $13,0 \mathrm{mg} / \mathrm{dL}-\mathrm{M}_{\mathrm{I}} 13,1 \mathrm{mg} / \mathrm{dL}-\mathrm{M}_{\mathrm{II}}$ $13,3 \mathrm{mg} / \mathrm{dL}-\mathrm{M}_{\mathrm{III}} 13,5 \mathrm{mg} / \mathrm{dL}-\mathrm{M}_{\mathrm{IV}} 13,8$ $\mathrm{mg} / \mathrm{dL}-\mathrm{M}_{\mathrm{V}} 13,9 \mathrm{mg} / \mathrm{dL}$. Sedangkan angka kadar $\mathrm{Hb}$ yang terendah ibu dengan nomor sampel 01 adalah hasil Pre-Test 9,1 mg/dL

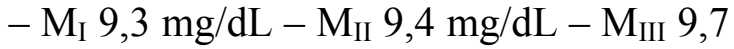
$\mathrm{mg} / \mathrm{dL}-\mathrm{M}_{\mathrm{IV}} 9,9 \mathrm{mg} / \mathrm{dL}-\mathrm{M}_{\mathrm{V}} 10,0 \mathrm{mg} / \mathrm{dL}$. 
Berdasarkan tabel distribusi responden menurut kelompok pemberian buah bit dapat dilihat bahwa terdapat ratarata selisih kadar hemoglobin sebelum dan sesudah mendapatkan intervensi buah bit sebanyak 4.000 gram selama 5 minggu adalah 12,0 $\mathrm{mg} / \mathrm{dL}$. Sedangkan selisih untuk kelompok yang tidak diberikan buah bit (kotrol) yaitu 9,5 mg/dL.

Berdasarkan distribusi rata-rata kadar hemoglobin kelompok eksperimen menurut pengukuran pre test dapat dilihat bahwa terjadi peningkatan rata-rata kadar hemoglobin ibu hamil trimester III sebesar $11,517 \mathrm{gr} / \mathrm{dl}$. Terdapat pengaruh konsumsi buah bit terhadap kadar hemoglobin ibu hamil dengan $\rho$ value lebih kecil dari nilai alpha $(0,05)$. Berdasarkan hasil uji beda $t$ test, menunjukkan bahwa secara statistik terdapat pengaruh konosumsi buah bit bagi ibu hamil trimester III terhadap peningkatan kadar hemoglobin $(p<0,005)$, dan peningkatan kadar $\mathrm{Hb}$ menurut pengukuran setelah diberikan buah but (post test) sebesar 11,517.

\section{SARAN}

1. Bagi ibu hamil trimester III sebaiknya mengkonsumsi makanan atau suplemen yang banyak mengandung sumber zat besi saat hamil.

2. Bagi UPTD Puskesmas Jeumpa dapat memberikan informasi kepada ibu hamil trimester III bahwa mengkonsumsi buah bit pada saat hamil dapat meningkatkan kadar hemoglobin dan mencegah terjadinya anemia.

3. Bagi Mahasiswa Institut Kesehatan Helvetia Medan dapat berpartisipasi dalam memberikan informasi tentang perbedaan kadar hemoglobin sebelum dan setelah pemberian buah bit pada ibu hamil trimester III.

4. Bagi Peneliti selanjutnya, dapat menjadi salah satu referensi untuk penelitian yang berhubungan dengan pemberian buah bit terhadap kenaikan kadar $\mathrm{Hb}$ ibu hamil trimester III.
DAFTAR PUSTAKA

Dinkes Aceh (2016). Profil Kesehatan Aceh Tahun 2016. Aceh: Dinas Kesehatan Aceh.

Iman, M. (2016). Panduan Penyusunan Karya Tulis Ilmiah Bidang Kesehatan Menggunakan Metode Ilmiah. Bandung: Cipta Pustaka Media Perintis.

Proverawati A, Siti A. (201). Anemia dan Anemia Kehamilan. Yogyakarta: Nuha Medika.

Sudasiah. Faktor-faktor yang berhubungan dengan Anemia pada Ibu Hamil Trimester III di Puskesmas Bumi Emas Kabupaten Lampung Timur tahun 2016: Jurnal Kesehatan-Akbid Wira Buana. Volume 1 No1. Edisi April 2017: 11-16.

Sugiyono. (2107). Metode Penelitian Kebijakan Pendekatan Kuantitatif Kualitatif Kombinasi R. D. dan Penelitian Evaluasi. Bandung: Alfabeta.

WHO. (2015). Worldwide prevalence of anemia 2013-2015. WHO global database on Anaemia Geneva, World Health Organization, 2015. Diperoleh tanggal 30 September 2017 dari http://www.who.int/vmnis/database/ anaemia/anaemia_data_status_t3/en. 